The new Journal of Bone and Joint Surgery is a symbol-a symbol of united effort by the nations of the world. In these circumstances we are proud to publish in the first British number a message from the King. His Majesty was anxious " not to let the appearance of this Journal pass without some mark of his approval." Surgeons throughout the Commonwealth and Empire will accept with devoted loyalty His Majesty's command to work in collaboration for the welfare of mankind. They rejoice that in this task it is their privilege to join with surgeons of the United States of America.

\title{
LOB'S WOOD
}

In the midsummer of 1947, fellows and associates of the British Orthopaedic Association sent a warm invitation to their colleagues in the United States to discuss the Journal of Bone and Joint Surgery. The American Orthopaedic Association and the Academy of Orthopaedic Surgeons were prompt in their response. Transatlantic air reservations were made within a few days. Dr R. I. Harris of Toronto travelled, not as the new leader of Canadian orthopaedic surgery, but as President-elect of the American Orthopaedic Association-a Canadian, with British traditions, thinking and speaking as an American-thus linking the Old World with the New. Dr William Rogers, Editor in Boston, came with all the benign and lovable qualities we respect and esteem. Dr Clay Ray Murray of New York-that gallant gentleman - laid aside personal problems and accepted the last duty of his life. Dr Earl McBride of Oklahoma represented, with accomplished charm but firmness of purpose, the younger orthopaedic surgeons and the Academy. Discussions were destined to take place in the President's room of the Royal College of Surgeons of England with its dignified atmosphere of history and tradition.

Surely it was by more than coincidence that the first week-end was spent resting in that very House-in-the-Wood in Surrey in which J. M. Barrie was for so long a welcome guest, and in which he was inspired to the whimsical writing of "Dear Brutus "-A Comedy in Three Acts. The words of Lob will be remembered: "It is all nonsense of course; just foolish talk of the villagers. They say that on Midsummer Eve there is a strange wood in this part of the country.... They say that in the wood you get what nearly everybody here is longing for-a second chance." British orthopaedic surgeons, young and old, who came to hold preliminary conversations with their American friends will remember that it was midsummer, we were "in the depths of the wood in the enchantment of a moonlight night," and we were given "our second chance." What will be our reaction? Will it be that of Margaret: "I don't want to be a might-have-been"? Will it be that of Purdie: "I feel there is something in me that will make me go on being the same however many chances I get"? Or will it be that of Joanna, on being reminded of Shakespeare's words: "The fault, dear Brutus, is not in our stars but in ourselves, that we are underlings" ?-

"Meaning that we have the power to shape ourselves?

"We have the power right enough.

" But isn't that rather splendid?

"For those who have the grit in them-Yes."

\section{BRITISH-AMERICAN AGREEMENT AND COMMONWEALTH GO-OPERATION}

In this number is recorded the agreement reached at the London Conference, held in the Royal College of Surgeons of England in May 1947, between representatives of the British and American Orthopaedic Associations. The agreement was confirmed at the Exeter and Manchester meetings of the British Orthopaedic Association and at the Hot Springs meeting of the American Orthopaedic Association. The new Journal of Bone and Joint Surgery is now established. It will be published every six weeks, four annual numbers being edited and 